\title{
HDL in sepsis - risk factor and therapeutic approach
}

\author{
Emily E. Morin ${ }^{1,2}$, Ling Guo ${ }^{3}$, Anna Schwendeman ${ }^{1,2 *}$ and Xiang-An $\mathrm{Li}^{3 *}$ \\ ${ }^{1}$ Department of Pharmaceutical Sciences, College of Pharmacy, University of Michigan, Ann Arbor, MI, USA, ${ }^{2}$ Biointerfaces \\ Institute, University of Michigan, Ann Arbor, MI, USA, ${ }^{3}$ Department of Pediatrics, Saha Cardiovascular Research Center, \\ University of Kentucky College of Medicine, Lexington, KY, USA
}

OPEN ACCESS

Edited by:

Norman Eric Miller,

University of Oxford, UK

Reviewed by:

Ghanshyam Upadhyay,

The City University of New York, USA

Salvatore Salomone,

University of Catania, Italy

*Correspondence:

Xiang-An Li

xli2@email.uky.edu;

Anna Schwendeman

annaschw@med.umich.edu

Specialty section:

This article was submitted to

Experimental Pharmacology and Drug

Discovery,

a section of the journa

Frontiers in Pharmacology

Received: 24 June 2015

Accepted: 08 October 2015

Published: 23 October 2015

Citation:

Morin EE, Guo L, Schwendeman A and $L i X-A$ (2015) HDL in sepsis - risk

factor and therapeutic approach.

Front. Pharmacol. 6:244.

doi: 10.3389/fphar.2015.00244
High-density lipoprotein (HDL) is a key component of circulating blood and plays essential roles in regulation of vascular endothelial function and immunity. Clinical data demonstrate that HDL levels drop by $40-70 \%$ in septic patients, which is associated with a poor prognosis. Experimental studies using Apolipoprotein A-I (ApoAl) null mice showed that HDL deficient mice are susceptible to septic death, and overexpressing ApoAl in mice to increase HDL levels protects against septic death. These clinical and animal studies support our hypothesis that a decrease in HDL level is a risk factor for sepsis, and raising circulating HDL levels may provide an efficient therapy for sepsis. In this review, we discuss the roles of HDL in sepsis and summarize the efforts of using synthetic HDL as a potential therapy for sepsis.

Keywords: high-density lipoprotein (HDL), apolipoprotein A-1 (ApoA1), sepsis, lipopolysaccharide (LPS), sepsis therapy

\section{INTRODUCTION}

Sepsis is a major health issue in the U. S., claiming over 215,000 lives and causing a financial burden exceeding $\$ 17$ billion annually (Martin et al., 2003; Riedemann et al., 2003; Angus and van der Poll, 2013). The prognosis for sepsis remains grim, with a mortality rate exceeding $30 \%$, due to poor understanding of the disease and a lack of efficient therapy (Sessler et al., 2004; Lagu et al., 2012; Dellinger et al., 2013).

A major contributor to sepsis mortality is the breakdown in the function of vascular endothelial cells (EC; Aird, 2003; Martin et al., 2003; Riedemann et al., 2003; Deanfield et al., 2007; Angus and van der Poll, 2013). As shown in Figure 1, this breakdown is caused by a cascade of inflammatory events-induced by infections, which includes three major factors/steps: (1) upon infections, bacteria release endotoxin; (2) endotoxin activates immune effector cells to produce inflammatory cytokines and chemokines; (3) inflammatory cytokines and chemokines activates EC, resulting in endothelial dysfunction manifested by vascular leakage, increased leukocyte adhesion, altered vascular tone and a shift in the hemostatic balance toward a pro-coagulant phenotype, which eventually leads to irreversible multi-organ failure and septic death (Aird, 2003; Martin et al., 2003; Riedemann et al., 2003; Deanfield et al., 2007; Angus and van der Poll, 2013). Thus, targeting endothelial dysfunction has been proposed as a potential sepsis therapy. A great challenge is that multiple factors/steps contribute to endothelial dysfunction in sepsis and simply targeting one of the regulatory factors/steps may have limited effect. Indeed, extensive efforts to block one or another component of the inflammatory or coagulation pathways have had little impact on patient survival (Fink and Warren, 2014). 


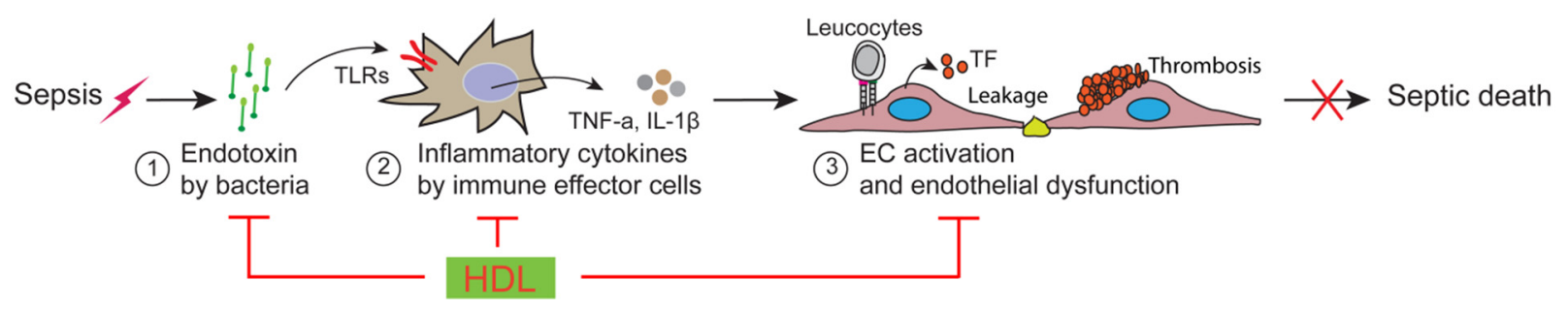

FIGURE 1 | Schematic model of vascular endothelial dysfunction in sepsis and high-density lipoprotein (HDL) protection against sepsis.

We believe that targeting an endogenous factor with multiprotective effects against endothelial dysfunction may present a novel approach for sepsis therapy. Emerging evidence suggests that High-density lipoprotein (HDL) is likely such a candidate. In this review, we discuss the roles of HDL in sepsis and summarize the efforts of using synthetic HDL (sHDL) as a potential therapy for sepsis.

\section{LOW HDL IS A RISK FACTOR FOR SEPSIS}

High-density lipoproteins (HDL) are nanosized protein-lipid particles that circulate throughout the body as a major component of the blood (Navab et al., 2011; Hewing et al., 2012; Zhu and Parks, 2012). Of its physiological functions, HDL is most notably known for its role in cholesterol mobilization and inflammation. HDL, via reverse cholesterol transport, removes cholesterol from peripheral cells and transports it to the liver for excretion in the bile or transport to the adrenals, testes, or ovaries for hormone production (von Eckardstein et al., 2001; Lewis and Rader, 2005; Ohashi et al., 2005; Vickers and Remaley, 2014). In several clinical investigations, plasma HDL levels was shown to be inversely correlated with the occurrence of cardiovascular diseases (CVDs), and many patients with severe CVD have very low levels of circulating HDL (Nofer et al., 2002; Barter et al., 2004; Remaley et al., 2008). Thus, HDL has long been sought after as a possible therapy for the reversal of atherosclerosis and other CVDs. However, HDL is also an important player in inflammation and acute inflammatory disorders. Specifically, HDL has been shown to exert anti-inflammatory properties both in vitro and in vivo (Harris et al., 2002; Barter et al., 2004; Mineo et al., 2006; Argraves and Argraves, 2007; De Nardo et al., 2014; Lüscher et al., 2014) and levels of HDL in patients with inflammatory disorders, such as sepsis, have been proven to be prognostic of clinical outcomes (Gordon, 2004; Riwanto and Landmesser, 2013).

High-density lipoprotein is a strong indicator of both the onset and progression of sepsis. Clinically, HDL levels drop markedly in septic patients, and whether or not these levels rise or continue to fall is often foretelling of their chance of survival (van Leeuwen et al., 2003; Chien et al., 2005; Tsai et al., 2009). In a study of 63 patients, investigators found that those with plasma HDL concentrations exceeding $25 \mathrm{mg} / \mathrm{dl}$ at the time of intake had a 100\% survival rate (Chien et al., 2005). Additionally, the investigators assessed the power of HDL to predict mortality rate by compartmentalizing patients into two groups: "low" $(<20 \mathrm{mg} / \mathrm{dl})$ and "high" ( $>20 \mathrm{mg} / \mathrm{dl})$ HDL. Using these cutoff values, HDL had a sensitivity of $92 \%$, a specificity of $80 \%$, and an accuracy of $83 \%$ for predicting the overall 30-day mortality rate (Chien et al., 2005). The same was done for ApoA1 levels using a cutoff value of $100 \mathrm{mg} / \mathrm{dL}$, however, ApoA1 showed an overall lower predictive value with an accuracy of $73 \%$ (Chien et al., 2005), aligning well with other studies showing that HDL, rather than lipid alone, is a better defender against septic shock (Levine et al., 1993).

Other investigations have also been carried out to determine whether low HDL causes septic death. Using ApoA1-null mice as a model for low circulating HDL, it was found that a deficiency in HDL leads to susceptibility to cecal ligation and puncture (CLP)induced septic death, as well both decreased LPS neutralization and LPS clearance(Guo et al., 2013). Alternatively, increasing HDL levels by over expression of ApoAI improved the survival in both CLP and LPS-induced sepsis models (Li et al., 2008; Guo et al., 2013). Given these clinical and experimental data, we propose that low HDL is a risk factor for sepsis and that targeting HDL may provide an efficient and effective therapy for sepsis.

\section{MECHANISMS OF HDL PROTECTION AGAINST SEPSIS}

High-density lipoprotein is a potential multi-protective factor in sepsis. HDL has a broad spectrum of activity, including regulating both immunity and vascular EC functions (Singh et al., 2007; Navab et al., 2011). While most of the existing knowledge of HDL has been acquired in non-sepsis conditions, extensive evidence suggests that HDL likely plays pivotal protective roles in all the steps of endothelial dysfunction (Figure 1), including detoxification of endotoxin, suppression of inflammatory signaling in immune effector cells and inhibition of EC activation.

\section{Detoxification of Endotoxin}

Bacterial infections are major causes of sepsis (Vincent et al., 2009). Upon infections, the Gram-negative bacteria release lipopolysaccharides (LPS) which bind to its receptor TLR4 to initiate a downstream signaling cascade. TLR4 binding leads to activation of proinflammatory genes to produce high levels 
of cytokines such as TNF- $\alpha$ and IL-6, resulting in cell damage (Raetz and Whitfield, 2002; Carmody and Chen, 2007). HDL is well known as a LPS neutralizer (Van Lenten et al., 1986; Flegel et al., 1989; Harris et al., 1990, 1993; Read et al., 1993; Eggesbo et al., 1996; Munford, 2005; Lee et al., 2007; Murch et al., 2007). Most LPS in circulation exist in HDL-bound form (Ulevitch et al., 1979, 1981), and HDL-LPS binding attenuates LPS-TLR4 inflammatory signaling in macrophages (Munford and Dietschy, 1985; Flegel et al., 1989; Baumberger et al., 1991; Emancipator et al., 1992). It is worth noting that simply neutralization of LPS may not provide efficient protection against sepsis which is shown by the failure of anti-LPS monoclonal antibodies in clinical trials (Cohen, 1999). We speculate that the failure of anti-LPS monoclonal antibodies in clinical trials could be attributed to: (i) the apparent inability of antibodies to block LPS-induced cytokine production in human monocytes in vitro (Warren et al., 1993; Cohen, 1999); and (ii) the fact that antibody partially sequester LPS, thus delaying rather than facilitating its clearance (Van Amersfoort et al., 2003). Recent studies including ours suggest that HDL acts together with its receptor, the scavenger receptor $\mathrm{BI}$ (SR-BI), to promote LPS clearance (Vishnyakova et al., 2003; Cai et al., 2008; Guo et al., 2009). In vitro, HDL promotes SR-BI-mediated LPS uptake by 4 fold in SR-BI-transfected HEK cells and by twofold in primary hepatocytes (Cai et al., 2008). In vivo, mice deficient in SR-BI or HDL display impaired LPS clearance in LPS or CLP animal models (Cai et al., 2008; Guo et al., 2009, 2013). These findings suggest that HDL neutralizes LPS and promotes LPS clearance via SR-BI-mediated LPS uptake, which presents a more efficient mechanism for LPS detoxification relative to neutralization by anti-LPS antibodies.

Lipoteichoic acid (LTA), released by Gram-positive bacteria, activates the TLR2/6 pathway to generate high levels of inflammatory cytokines, causing cell injury. Similar to LPS, most LTA are associated with HDL in circulation and this HDL-LTA binding neutralizes LTA (Grunfeld et al., 1999; Levels et al., 2001). Given the structural similarity between LPS and LTA, it is likely that HDL neutralizes LTA and promotes LTA clearance via SR-BI-mediated LTA uptake.

\section{Regulating Inflammatory Response in Macrophages}

Macrophages are major immune effector cells responsible for inflammatory cytokine production in sepsis (Su, 2002). The inflammatory response in macrophages is required for fighting against infections. However, dysregulation of macrophages produces too many cytokines, leading to vascular endothelial dysfunction and organ injury in sepsis. A body of evidence indicates that HDL is a key modulator of inflammatory response in macrophages (Yvan-Charvet et al., 2008; Zhu et al., 2008; Suzuki et al., 2010; Mineo and Shaul, 2012; Zhu and Parks, 2012; De Nardo et al., 2014): (i) HDL promotes the efflux of free cholesterol from macrophages, resulting in suppression of LPS-induced inflammatory response in macrophages (Mendez et al., 2001; Puff et al., 2005); and ii) HDL upregulates the transcriptional regulator ATF3 which down regulates the expression of inflammatory molecules, resulting in suppression of the inflammatory response in sepsis (De Nardo et al., 2014).

\section{Regulating Endothelial Cell Function}

Endothelial cells are activated by LPS and inflammatory cytokines (Aird, 2003; Deanfield et al., 2007; Shapiro et al., 2010). As discussed above, HDL can attenuate EC activation through its roles in promoting LPS detoxification and suppressing inflammatory cytokine production in macrophages. In addition, earlier studies demonstrated that HDL has a variety of activities that modulates EC functions, including: (i) inhibition of adhesion molecule expression stimulated by TNF- $\alpha$, IL- $1 \beta$ or thrombin (Cockerill et al., 1995, 1999); (ii) activation of eNOS. NO generated by eNOS at small blood vessels is critical for promoting blood supply to small blood vessels and for inhibiting thrombosis in sepsis. Earlier studies including ours demonstrated that HDL activates eNOS to release NO in a SR-BI-dependent manner (Yuhanna et al., 2001; Li et al., 2002; Gong et al., 2003; Mineo et al., 2003); and (iii) prevention of endothelial thrombotic activation by promoting prostacyclin and Cox 2 production and suppressing tissue factor and adhesion molecule expression (Ming et al., 2004; Viswambharan et al., 2004; Riwanto and Landmesser, 2013).

In conclusion, HDL likely plays critical roles in promoting LPS/LTA detoxification, suppressing inflammatory response in macrophages and inhibiting EC activation, which may present HDL a multi-protective factor against endothelial dysfunction in sepsis.

\section{SYNTHETIC HDL IS A POTENTIAL EFFECTIVE THERAPY FOR SEPSIS}

Reconstituted or sHDL made from ApoAI protein or ApoAI mimetic peptide presents a new strategy for promoting the biological activity of HDL (Krause and Remaley, 2013). Experimental and clinical investigations, including phase 2 clinical trials for treatment of CVD, have shown that infusion of sHDL raises circulating HDL levels, improves endothelial function and reduces platelet aggregation (Patel et al., 2009; Krause and Remaley, 2013), and with HDL levels at the time of hospitalization being positively correlated with increased survival rates among septic patients (Barlage et al., 2009), it is reasonable that HDL replacement therapy has been a well sought-after area of sepsis research. Not only does HDL confer cardio-protection via maintaining endothelial barrier integrity and reverse cholesterol transport, it is also able to combat inflammation and oxidization, as shown both in vitro and in vivo (Pajkrt et al., 1996). Several studies have been carried out in order to investigate the protective ability of administered HDL against endotoxemia, a few of which are discussed below, and can be found summarized in Table 1.

\section{ApoA1}

Since ApoA1 is the main protein component of HDL, it makes sense that administering additional ApoA1 protein can increase 
TABLE 1 | Experimental high-density lipoprotein (HDL) therapies in animals models of sepsis and their outcomes.

\begin{tabular}{|c|c|c|c|c|}
\hline HDL & Dose and administration & Sepsis model & Main findings & Reference \\
\hline $\begin{array}{l}\text { 18A:Egg PC } \\
(1: 2 w t / w t) \\
\text { sHDL }\end{array}$ & $\begin{array}{l}80 \text { mg/kg; prophylactic tail vein IV } \\
\text { infusion }\end{array}$ & $\begin{array}{l}\text { Swiss Webster mice; } \\
\text { LPS (salmonella) } 10 \text { mg/kg; IP } \\
\text { injection; within } 15 \text { min of HDL }\end{array}$ & $\begin{array}{l}\text { Three-fourfold increase in } 48-h \\
\text { survival rate vs control }(p<0.05)\end{array}$ & Levine et al., 1993 \\
\hline L-4F Peptide & $\begin{array}{l}25 \text { mg/kg, IP, concurrently with } \\
\text { lipopolysaccharide (LPS) }\end{array}$ & $\begin{array}{l}\text { Sprague-Dawley rats; } 10 \text { mg/kg } \\
\text { LPS; IP injection }\end{array}$ & $\begin{array}{l}\text { Reduction in VCAM-1 expression in } \\
\text { excised aortae }\end{array}$ & Gupta et al., 2005 \\
\hline 4F Peptide & $\begin{array}{l}10 \text { mg/kg; IP injection post-LPS } \\
\text { challenge }\end{array}$ & $\begin{array}{l}\text { Sprague-Dawley rats; LPS } \\
10 \text { mg/kg or } 30 \text { mg/kg; IP injection }\end{array}$ & $\begin{array}{l}10 \text { mg/kg LPS: } 4 F \text { slowed LPS } \\
\text { plasma clearance; reduced } \\
\text { hypotension at } 6 \text { h; } \\
30 \text { mg/kg LPS: } 4 \text { F increased plasma } \\
\text { HDL levels; increased 24-h survival }\end{array}$ & Dai et al., 2010 \\
\hline 4F Peptide & 10 mg/kg, IP, 6 h post-CLP & Sprague-Dawley rats; CLP & $\begin{array}{l}\text { Reduced IL-6; restored } \mathrm{CO} \text {, right } \\
\text { atrial pressure, and plasma volume; } \\
\text { improved } 2 \text {-day survival rate; } \\
\text { reversed sepsis-induced changes in } \\
\text { lipoprotein profile }\end{array}$ & Zhang et al., 2009 \\
\hline 4F Peptide & $\begin{array}{l}10 \mathrm{mg} / \mathrm{kg} ; \mathrm{IP} \text { injection } 6 \mathrm{~h} \\
\text { post-cecal ligation and puncture } \\
(\mathrm{CLP})\end{array}$ & Wistar Rats; CLP & $\begin{array}{l}\text { Restored renal, hepatic, and cardiac } \\
\text { functions; reduced renal tubule } \\
\text { damage; restored expression levels } \\
\text { of Slit2, Robo4, and eNOS; } \\
\text { increased plasma HDL; improved } \\
\text { 4-day survival; no change in MAP }\end{array}$ & Moreira et al., 2014 \\
\hline D-4F Peptide & $20 \mu \mathrm{g}$ daily for 9 days; IP injection & $\begin{array}{l}\text { C57BL/6J mice; nasally } \\
\text { innoculated with } 10^{5} \mathrm{PFU} \text { influenza } \\
\text { virus AWSN/33 }\end{array}$ & $\begin{array}{l}\text { Prevented lymphoid hyperplasia; } \\
\text { increased PON activity; prevented } \\
\text { drop in core body temperature; } \\
\text { suppressed plasma IL-6 levels; } \\
\text { increased plasma HDL and inhibited } \\
\text { lipoprotein alteration; reduced viral } \\
\text { titers by }>50 \% \text { at all time points }\end{array}$ & $\begin{array}{l}\text { Van Lenten et al., } \\
2002\end{array}$ \\
\hline ApoA1 & $\begin{array}{l}10 \text { mg/kg; IP injection } 1 \mathrm{~h} \text { post-LPS } \\
\text { challenge }\end{array}$ & $\begin{array}{l}\text { Wistar rats; LPS } 1 \mathrm{mg} / \mathrm{kg} \text { (TNF } \\
\text { analysis) or } 5 \mathrm{mg} / \mathrm{kg} \text { (survival } \\
\text { study); IP injection }\end{array}$ & $\begin{array}{l}\text { Reduced plasma TNF- } \alpha \text { levels in rats } \\
\text { given } 1 \mathrm{mg} / \mathrm{kg} \text { LPS; increased } 5 \text {-day } \\
\text { survival rate from } 0 \text { to } 90 \% \text { in rats } \\
\text { given } 5 \mathrm{mg} / \mathrm{kg} \text { LPS }\end{array}$ & Imai et al., 2003 \\
\hline $\begin{array}{l}\text { ApoA1, human plasma } \\
\text { purified }\end{array}$ & $\begin{array}{l}100 \mathrm{mg} / \mathrm{kg} ; \text { IV infusion post-LPS } \\
\text { challenge }\end{array}$ & $\begin{array}{l}\text { Balb/c mice; LPS } 5 \text { mg/kg; IP } \\
\text { injection }\end{array}$ & $\begin{array}{l}\text { Increased both survival rate and } \\
\text { average survival time over } 3 \text { days }\end{array}$ & Yan et al., 2006 \\
\hline $\begin{array}{l}\text { ApoA1 Milano } \\
\text { ApoA1:Soy PC } \\
(1: 3.35 \mathrm{~mol} / \mathrm{mol}) \\
\mathrm{rHDL}\end{array}$ & 40 mg/kg; prophylactic IV injection & $\begin{array}{l}\text { Wistar rats; } 400 \text { EU/kg } \\
\text { Gram-negative bacterial endotoxin; } \\
\text { IV injection }\end{array}$ & $\begin{array}{l}\text { Increase in HDL-C; improved renal } \\
\text { and hepatic function; inhibition of } \\
\text { cytokines TNF- } \alpha, \text { IL-1 } 1 \beta, \text { IL- } 6 \text {; } \\
\text { reduced expression of ICAM-1 }\end{array}$ & Zhang et al., 2015 \\
\hline $\begin{array}{l}\text { ApoA1:Soy PC } \\
(1: 200 \mathrm{~mol} / \mathrm{mol}) \\
\text { rHDL }\end{array}$ & $\begin{array}{l}75 \text { mg/kg ApoA1; prophylactic } \\
\text { continuous IV infusion over } 25 \text { min }\end{array}$ & $\begin{array}{l}\text { NZW rabbits; LPS } 25 \mu \mathrm{g} / \mathrm{kg} \\
\text { continuous IV infusion over } 6 \text { h; } \\
\text { start } 20 \text { min post-rHDL treatment }\end{array}$ & $\begin{array}{l}\text { Complete inhibition of TNF- } \alpha \text {; } \\
\text { prevented LPS-induced } \\
\text { hypotension; reduced metabolic } \\
\text { acidosis; no significant effect on } \\
\text { serum LPS levels }\end{array}$ & Hubsch et al., 1993 \\
\hline $\begin{array}{l}\text { ApoA1:Egg PC } \\
(1: 2 \mathrm{w} / \mathrm{w}) \\
\mathrm{rHDL}\end{array}$ & $\begin{array}{l}500 \mathrm{mg} / \mathrm{kg} \text { ApoA1; IV infusion at } \\
0.1 \mathrm{~g} / \mathrm{kg} / \mathrm{hr} \text {; split into three doses: } \\
0.3,0.1 \text {, and } 0.1 \mathrm{~g} / \mathrm{kg} \text { administered } \\
\text { at } 0.5,8 \text {, and } 16 \mathrm{~h} \text { post-infection, } \\
\text { respectively }\end{array}$ & $\begin{array}{l}\text { 2-year old Beagles surgically } \\
\text { implanted with E. coli-infected fibrin } \\
\text { clot }\end{array}$ & $\begin{array}{l}\text { Reduced plasma endotoxin levels; } \\
\text { decreased plasma TNF- } \alpha \text {; } \\
\text { decreased liver function; decreased } \\
\text { 2-day survival and average survival } \\
\text { time }\end{array}$ & $\begin{array}{l}\text { Quezado et al., } \\
1995\end{array}$ \\
\hline $\begin{array}{l}\text { CSL-111 } \\
\text { ApoA1:Soy PC } \\
(1: 150 \mathrm{~mol} / \mathrm{mol}) \\
\text { rHDL }\end{array}$ & $\begin{array}{l}75 \text { mg/kg ApoA1; } \\
\text { (a) Prophylactic IV infusion over } \\
40 \text { min } \\
\text { (b) Treatment by IV infusion over } \\
20 \text { min, } 1 \text { h post-bacterial challenge }\end{array}$ & $\begin{array}{l}\text { NZW Rabbits } \\
\text { (1) Gram (-) Sepsis: } \\
4 \times 10^{9} \text { CFU/kg E. coli; IV infusion } \\
\text { over } 2 \text { h } \\
\text { (2) Gram (+) Sepsis: } \\
2 \times 10^{9} \text { CFU/kg; IV infusion over } \\
2 \text { h }\end{array}$ & $\begin{array}{l}\text { (1 a) Prophylactic rHDL: reduced } \\
\text { plasma LPS and TNF- } \alpha \text {; reduction in } \\
\text { metabolic acidosis; no effect on } \\
\text { hypotension or blood bacterial levels } \\
\text { (1 b) rHDL Treatment: reduction in } \\
\text { LPS after } 4 \text { h; reduced metabolic } \\
\text { acidosis and creatinine; no effect on } \\
\text { blood bacterial counts or TNF- } \alpha \text {; no } \\
\text { effect on hypotension } \\
\text { (2) No effect in Gram (+) sepsis }\end{array}$ & Hubsch et al., 1995 \\
\hline
\end{tabular}

(Continued) 
TABLE 1 | Continued

\begin{tabular}{|c|c|c|c|c|}
\hline HDL & Dose and administration & Sepsis model & Main findings & Reference \\
\hline $\begin{array}{l}\text { CSL-111 } \\
\text { ApoA1:Soy PC } \\
(1: 150 \mathrm{~mol} / \mathrm{mol}) \\
\text { rHDL }\end{array}$ & $\begin{array}{l}25 \text { or } 50 \text { mg/kg ApoA1; } \\
\text { Prophylactic IV infusion over } 40 \text { min }\end{array}$ & $\begin{array}{l}\text { NZW rabbits; LPS } 10 \mu \mathrm{g} / \mathrm{kg} \text {; } \\
\text { continuous IV infusion over } 2 \text { h; } \\
\text { start } 15 \text { min post-rHDL completion }\end{array}$ & $\begin{array}{l}\text { Reduced TNF- } \alpha \text { levels and } \\
\text { increased TNF- } \alpha \text { clearance for both } \\
\text { rHDL doses; rHDL } 50 \text { mg/kg } \\
\text { reduced hypotension at } t=3-4 \text { h; } \\
\text { no effect on plasma LPS levels; no } \\
\text { effect on blood leukocyte count }\end{array}$ & Casas et al., 1995 \\
\hline $\begin{array}{l}\text { CSL-111 } \\
\text { ApoA1:Soy PC } \\
(1: 150 \mathrm{~mol} / \mathrm{mol}) \\
\text { rHDL }\end{array}$ & $\begin{array}{l}40 \text { mg/kg; prophylactic IV infusion } \\
\text { over } 4 \mathrm{~h}\end{array}$ & $\begin{array}{l}\text { Healthy male volunteers } \\
\text { (20-28 years); Endotoxin } 4 \text { ng/kg IV } \\
\text { bolus; given } 3.5 \text { h post-rHDL start }\end{array}$ & $\begin{array}{l}\text { Elevated HDL levels; reduced } \\
\text { endotoxin-induced clinical } \\
\text { symptoms, i.e., chills, myalgia, } \\
\text { backache, nausea, and vomiting; } \\
\text { reduced plasma cytokine levels of } \\
\text { TNF- } \alpha \text {, IL-6, and IL-8; inhibited } \\
\text { early leukopenia, monopenia, and } \\
\text { neutropenia; reduced monocyte } \\
\text { CD14 expression }\end{array}$ & Pajkrt et al., 1996 \\
\hline
\end{tabular}

circulating levels of HDL, avoiding the need to reconstitute with lipid, which adds an additional level of complexity. Administration of naked ApoA1 purified from human plasma has shown to have some beneficial effects in both rat and mouse LPS-induced endotoxemia models. When administered at $10 \mathrm{mg} / \mathrm{kg}$ (IP) $1 \mathrm{~h}$ post-infection, ApoA1 increased the 5-day survival rate from 0 to $90 \%$ in rats given $5 \mathrm{mg} / \mathrm{kg}$ LPS (Imai et al., 2003). In a similar model in mice, ApoA 1 dosed $1 \mathrm{~h}$ post-infection via intravenous (IV) infusion at $100 \mathrm{mg} / \mathrm{kg}$ increased both 3 day survival rate and overall survival time versus saline-treated controls (Yan et al., 2006). Additionally, it was found that ApoA1 overexpressing mice were more resistant to infection than those with normal or decreased levels of circulating ApoA1 (Li et al., 2008).

\section{ApoA1 Milano}

ApoA1 Milano is a naturally occurring variant of ApoA1 found in a select subset of individuals. Those carrying this mutation, despite having markedly lower levels of circulating HDL, have a much lower risk of developing CVD than their wild-type counterparts (Nissen et al., 2003; Nicholls et al., 2011). It was since developed as an reconstituted HDL (rHDL) therapy by Esperion Therapeutics where it entered a Phase I trial (Nicholls et al., 2011), however, after being licensed to Pfizer it forewent further clinical trials. While a majority of research around ApoA1 Milano is focused around CVD, rHDL using this variant protein $\left(\mathrm{rHDL}_{\mathrm{M}}\right)$ has also been shown to be efficacious against inflammation (Zhang et al., 2015). In a Gram-negative bacterial rat model, $\mathrm{rHDL}_{\mathrm{M}}$ given prophylactically at $40 \mathrm{mg} / \mathrm{kg}$ was effective in suppressing proinflammatory cytokines TNF- $\alpha$, IL-1 $\beta$, and IL-6 (Zhang et al., 2015). Additionally, rats dosed with $\mathrm{rHDL}_{\mathrm{M}}$ displayed increased renal and hepatic function as well as a decrease in cardiac tissue damage when compared to saline-treated controls (Zhang et al., 2015).

\section{CSL-111}

CSL-111 is a rHDL originally produced by CSL Behring for the intention of treating atherosclerosis, making it through
Phase II Clinical Trial before being superseded by CSL-112, CSL Behring's current investigational rHDL therapeutic (Tardif et al., 2007). Made from purified human ApoA1 and soybean phosphatidylcholine (PC) at a molar ratio of $1: 2$ protein to lipid, CSL-111 has repeatedly shown efficacy in reducing the burden of LPS-induced endotoxemia both in vitro and in vivo in rabbit and human models (Casas et al., 1995; Hubsch et al., 1995; Pajkrt et al., 1996). In doses ranging from 25 to $75 \mathrm{mg} / \mathrm{kg}$ body weight, CSL-111 was able to suppress production of proinflammatory cytokines TNF- $\alpha$, IL-6, and IL-8 (Hubsch et al., 1995; Pajkrt et al., 1996), inhibit sepsis-induced hypotension (Casas et al., 1995; Pajkrt et al., 1996), and markedly decrease the severity of clinical symptoms when administered prophylactically (Pajkrt et al., 1996). Although CSL-111 showed less promise when administered as treatment $1 \mathrm{~h}$ post-bacterial challenge, it was still able to reduce the degree metabolic acidosis and improve kidney function over saline controls in rabbit models (Hubsch et al., 1995).

\section{HDL Mimetic Peptides}

While HDL therapy may be a feasible solution in the treatment of sepsis, the ability to produce therapeutic quantities of HDL is both a rate- and cost-limiting process in its development. For this reason, the use of ApoA1 mimetic peptides has gained increasing popularity, as they are a cheaper and easier way to make HDL-like particles.

Several mimetic peptides have been synthesized and studied to date, all of which are structurally similar to the amphipathic alpha-helices of native ApoA1 (Navab et al., 2005). Both in vitro and in vivo these peptides are able to bind phospholipids and associate with native HDL particles (Navab et al., 2005, 2011). Functionally, these mimetic peptides are able to reproduce the role of native HDL in their ability to efflux cholesterol (Sethi et al., 2008; Amar et al., 2010), interact with HDL receptors, i.e., ABCA1, ABCG1, and SR-B1 (Sethi et al., 2008), as well as interact with HDL-associated enzymes LCAT and PON (Van Lenten et al., 2002; Chen et al., 2009; Navab et al., 2011), and most relevant to sepsis, the ability to bind and neutralize LPS (Gupta et al., 2005; Remaley et al., 2008). 


\section{A Peptide}

One of the first HDL mimetic peptides to be investigated is the 18 amino acid peptide, 18A (DWLKAFYDKVAEKLKEAF). This peptide closely mimics the amphipathic alpha-helical structure of ApoA1, rendering it suitable for sHDL studies. In vivo, prophylactic infusion of 18A sHDL composed of 18A:Egg PC at a 1:2 weight ratio increased the survival rate three-fourfold over saline-treated controls in Swiss Webster mice infected with LPS from salmonella (Levine et al., 1993). Since, 18A peptide has been modified to create $4 \mathrm{~F}$ peptide, which is discussed below.

\section{F Peptide}

$4 \mathrm{~F}$ is an 18 amino acid peptide (DWFKAFYDKVAEKFKEAF) derived from the sequence of $18 \mathrm{~A}$, replacing two lysine residues with phenylalanine (Navab et al., 2005). 4F peptide has been the focus of several studies, and is synthesized using either L- or D-amino acids ( $\mathrm{L}-4 \mathrm{~F}$ and D-4F, respectively). D-4F is of particular interest to researchers because it can be delivered orally due its resistance to enzymatic degradation (Navab et al., 2005). In a mouse influenza model, D-4F was able to suppress IL-6 production, prevent lymphoid hyperplasia, maintain normal core body temperatures, and reduce viral titers by $>50 \%$ over the entire course of study when administered intraperitoneally at doses of $20 \mu \mathrm{g}$ daily (Van Lenten et al., 2002). L-4F has been more widely studied in the context of sepsis, and has been shown to be efficacious in both rat CLP and LPS-induced endotoxemia models at doses as low as $10 \mathrm{mg} / \mathrm{kg}$ body weight (Gupta et al., 2005; Zhang et al., 2009; Dai et al., 2010; Moreira et al., 2014). In such studies, L-4F administered by IP injection was shown to block production of cytokines TNF- $\alpha$ and IL-6, reverse sepsisinduced hypotension, prevent organ damage, and restore renal, hepatic, and cardiac function, and increase both survival rate and average survival time in comparison to saline-treated controls (Gupta et al., 2005; Zhang et al., 2009; Dai et al., 2010; Moreira

\section{REFERENCES}

Aird, W. C. (2003). The role of the endothelium in severe sepsis and multiple organ dysfunction syndrome. Blood 101, 3765-3777. doi: 10.1182/blood-200206-1887

Amar, M. J. A., D’Souza, W., Turner, S., Demosky, S., Sviridov, D., Stonik, J., et al. (2010). 5A apolipoprotein mimetic peptide promotes cholesterol efflux and reduces atherosclerosis in mice. J. Pharmacol. Exp. Therapeut. 334, 634-641. doi: 10.1124/jpet.110.167890

Angus, D. C., and van der Poll, T. (2013). Severe sepsis and septic shock. N. Engl. J. Med. 369, 840-851. doi: 10.1056/NEJMra1208623

Argraves, K. M., and Argraves, W. S. (2007). HDL serves as a S1P signaling platform mediating a multitude of cardiovascular effects. J. Lipid Res. 48, 2325-2333. doi: 10.1194/jlr.R700011-JLR200

Barlage, S., Gnewuch, C., Liebisch, G., Wolf, Z., Audebert, F.-X., Glück, T., et al. (2009). Changes in HDL-associated apolipoproteins relate to mortality in human sepsis and correlate to monocyte and platelet activation. Intensive Care Med. 35, 1877-1885. doi: 10.1007/s00134-0091609-y

Barter, P. J., Nicholls, S., Rye, K.-A., Anantharamaiah, G. M., Navab, M., and Fogelman, A. M. (2004). Antiinflammatory properties of HDL. Circ. Res. 95, 764-772. doi: 10.1161/01.res.0000146094.59640.13

Baumberger, C., Ulevitch, R. J., and Dayer, J. M. (1991). Modulation of endotoxic activity of lipopolysaccharide by high-density lipoprotein. Pathobiology 59, 378-383. doi: 10.1159/000163681 et al., 2014). Most notably, L-4F was given after infection, rather than prophylactically, representing a more clinically relevant application and meriting its further investigation as a potential therapeutic.

\section{Prospectives in sHDL Sepsis Therapy}

While previous studies have shown encouraging results, the earlier generation of sHDL and naked ApoAI mimetic peptides suffer from poor purity, short circulation times, contaminations, and toxicity (Quezado et al., 1995; DiPiro et al., 1996; Tardif et al., 2007; Zhang et al., 2009). It is worth noting that the current literature describing sHDL largely focuses on its protein/peptide composition and on its capacity in mediating cholesterol efflux. Considering that sHDL likely plays multiprotective roles in sepsis and the lipid components significantly alter the properties of sHDL, further efforts are required to understand these protective roles and tailor sHDL composition for increased efficacy in sepsis. Extensive efforts have been made to understand the roles of HDL/sHDL in CVD and other chronic inflammatory diseases, and these studies have profoundly improved our understanding about HDL/sHDL. We may take these advantages to further determine the roles of HDL/sHDL in the context of sepsis and develop the new generation of sHDL for sepsis therapy.

\section{FUNDING}

This publication was made possible by Grant Number R01GM113832 (to X-AL and AS) from NIGMS/NIH, AHA 13SDG17230049 (AS), and NIH T32 GM008353 (EM). Its contents are solely the responsibility of the authors and do not necessarily represent the official views of the NIGMS, NIH, or AHA.

Cai, L., Ji, A., de Beer, F. C., Tannock, L. R., and van der Westhuyzen, D. R. (2008). SR-BI protects against endotoxemia in mice through its roles in glucocorticoid production and hepatic clearance. J. Clin. Invest. 118, 364-375. doi: 10.1172/JCI31539

Carmody, R. J., and Chen, Y. H. (2007). Nuclear factor-kappaB: activation and regulation during toll-like receptor signaling. Cell. Mol. Immunol. 4, 31-41.

Casas, A. T., Hubsch, A. P., Rogers, B. C., and Doran, J. E. (1995). Reconstituted high-density lipoprotein reduces LPS-stimulated TNF $\alpha$. J. Surg. Res. 59, 544552. doi: 10.1006/jsre.1995.1204

Chen, X., Burton, C., Song, X., McNamara, L., Langella, A., Cianetti, S., et al. (2009). An apoA-I mimetic peptide increases LCAT activity in mice through increasing HDL concentration. Int. J. Biol. Sci. 5, 489-499. doi: 10.7150/ijbs.5.489

Chien, J. Y., Jerng, J. S., Yu, C. J., and Yang, P. C. (2005). Low serum level of highdensity lipoprotein cholesterol is a poor prognostic factor for severe sepsis. Crit. Care Med. 33, 1688-1693. doi: 10.1097/01.CCM.0000171183.79525.6B

Cockerill, G. W., Rye, K.-A., Gamble, J. R., Vadas, M. A., and Barter, P. J. (1995). High-density lipoproteins inhibit cytokine-induced expression of endothelial cell adhesion molecules. Arterioscler. Thromb. Vasc. Biol. 15, 1987-1994. doi: 10.1161/01.atv.15.11.1987

Cockerill, G. W., Saklatvala, J., Ridley, S. H., Yarwood, H., Miller, N. E., Oral, B., et al. (1999). High-density lipoproteins differentially modulate cytokineinduced expression of e-selectin and cyclooxygenase-2. Arterioscler. Thromb. Vasc. Biol. 19, 910-917. doi: 10.1161/01.atv.19.4.910

Cohen, J. (1999). Adjunctive therapy in sepsis: a critical analysis of the clinical trial programme. Br. Med. Bull. 55, 212-225. doi: 10.1258/0007142991902222 
Dai, L., Datta, G., Zhang, Z., Gupta, H., Patel, R., Honavar, J., et al. (2010). The apolipoprotein A-I mimetic peptide $4 \mathrm{~F}$ prevents defects in vascular function in endotoxemic rats. J. Lipid Res. 51, 2695-2705. doi: 10.1194/jlr.M008086

De Nardo, D., Labzin, L. I., Kono, H., Seki, R., Schmidt, S. V., Beyer, M., et al. (2014). High-density lipoprotein mediates anti-inflammatory reprogramming of macrophages via the transcriptional regulator ATF3. Nat. Immunol. 15, 152-160. doi: 10.1038/ni.2784

Deanfield, J. E., Halcox, J. P., and Rabelink, T. J. (2007). Endothelial function and dysfunction: testing and clinical relevance. Circulation 115, 1285-1295. doi: 10.1161/circulationaha.106.652859

Dellinger, R. P., Levy, M. M., Rhodes, A., Annane, D., Gerlach, H., Opal, S. M., et al. (2013). Surviving sepsis campaign: international guidelines for management of severe sepsis and septic shock: 2012. Crit. Care Med. 41, 580-637. doi: 10.1097/CCM.0b013e31827e83af

DiPiro, J. T., Cue, J. I., Richards, C. S., Hawkins, M. L., Doran, J. E., and Mansberger, A. R. (1996). Pharmacokinetics of reconstituted human highdensity lipoprotein in pigs after hemorrhagic shock with resuscitation. Crit. Care Med. 24, 440-444. doi: 10.1097/00003246-199603000-00013

Eggesbo, J. B., Lyberg, T., Aspelin, T., Hjermann, I., and Kierulf, P. (1996). Different binding of 125I-LPS to plasma proteins from persons with high or low HDL. Scand. J. Clin. Lab. Invest. 56, 533-543. doi: 10.3109/003655196090 88809

Emancipator, K., Csako, G., and Elin, R. J. (1992). In vitro inactivation of bacterial endotoxin by human lipoproteins and apolipoproteins. Infect. Immun. 60, 596-601.

Fink, M. P., and Warren, H. S. (2014). Strategies to improve drug development for sepsis. Nat. Rev. Drug Discov. 13, 741-758. doi: 10.1038/nrd4368

Flegel, W. A., Wolpl, A., Mannel, D. N., and Northoff, H. (1989). Inhibition of endotoxin-induced activation of human monocytes by human lipoproteins. Infect. Immun. 57, 2237-2245.

Gong, M., Wilson, M., Kelly, T., Su, W., Dressman, J., Kincer, J., et al. (2003). HDL-associated estradiol stimulates endothelial NO synthase and vasodilation in an SR-BI-dependent manner. J. Clin. Invest. 111, 1579-1587. doi: 10.1172/JCI16777

Gordon, B. R. (2004). Poor outcomes associated with low lipid and lipoprotein levels*. Crit. Care Med. 32, 878-879. doi: 10.1097/01.CCM.0000117318.84442.9F

Grunfeld, C., Marshall, M., Shigenaga, J. K., Moser, A. H., Tobias, P., and Feingold, K. R. (1999). Lipoproteins inhibit macrophage activation by lipoteichoic acid. J. Lipid Res. 40, 245-252.

Guo, L., Ai, J., Zheng, Z., Howatt, D. A., Daugherty, A., Huang, B., et al. (2013). High density lipoprotein protects against polymicrobe-induced sepsis in mice. J. Biol. Chem. 288, 17947-17953. doi: 10.1074/jbc.M112.44 2699

Guo, L., Song, Z., Li, M., Wu, Q., Wang, D., Feng, H., et al. (2009). Scavenger receptor BI protects against septic death through its role in modulating inflammatory response. J. Biol. Chem. 284, 19826-19834. doi: 10.1074/jbc.M109.020933

Gupta, H., Dai, L., Datta, G., Garber, D. W., Grenett, H., Li, Y., et al. (2005). Inhibition of lipopolysaccharide-induced inflammatory responses by an apolipoprotein ai mimetic peptide. Circ. Res. 97, 236-243. doi: 10.1161/01.res.0000176530.66400.48

Harris, H. W., Grunfeld, C., Feingold, K. R., and Rapp, J. H. (1990). Human very low density lipoproteins and chylomicrons can protect against endotoxin-induced death in mice. J. Clin. Invest. 86, 696-702. doi: 10.1172/ JCI114765

Harris, H. W., Grunfeld, C., Feingold, K. R., Read, T. E., Kane, J. P., Jones, A. L., et al. (1993). Chylomicrons alter the fate of endotoxin, decreasing tumor necrosis factor release and preventing death. J. Clin. Invest. 91, 1028-1034. doi: 10.1172/JCI116259

Harris, H. W., Johnson, J. A., and Wigmore, S. J. (2002). Endogenous lipoproteins impact the response to endotoxin in humans. Crit. Care Med. 30, 23-31. doi: 10.1097/00003246-200201000-00004

Hewing, B., Moore, K. J., and Fisher, E. A. (2012). HDL and cardiovascular risk. Circ. Res. 111, 1117-1120. doi: 10.1161/circresaha.112.280958

Hubsch, A. P., Casas, A. T., and Doran, J. E. (1995). Protective effects of reconstituted high-density lipoprotein in rabbit gram-negative bacteremia models. J. Lab. Clin. Med. 126, 548-558.
Hubsch, A. P., Powell, F. S., Lerch, P. G., and Doran, J. E. (1993). A reconstituted, ApoA1 containing lipoprotein reduces tumor necrosis factor release and attenuates shock in endotoxemic rabbits. Circ. Shock 40, 14-23.

Imai, T., Fujita, T., and Yamazaki, Y. (2003). Beneficial effects of apolipoprotein A-I on endotoxemia. Surg. Today 33, 684-687. doi: 10.1007/s00595-003-2585-4

Krause, B. R., and Remaley, A. T. (2013). Reconstituted HDL for the acute treatment of acute coronary syndrome. Curr. Opin. Lipidol. 24, 480-486. doi: 10.1097/MOL.0000000000000020

Lagu, T., Rothberg, M. B., Shieh, M. S., Pekow, P. S., Steingrub, J. S., and Lindenauer, P. K. (2012). Hospitalizations, costs, and outcomes of severe sepsis in the United States 2003 to 2007. Crit. Care Med. 40, 754-761. doi: 10.1097/CCM.0b013e318232db65

Lee, R. P., Lin, N. T., Chao, Y. F., Lin, C. C., Harn, H. J., and Chen, H. I. (2007). High-density lipoprotein prevents organ damage in endotoxemia. Res. Nurs. Health 30, 250-260. doi: 10.1002/nur.20187

Levels, J. H. M., Abraham, P. R., van den Ende, A., and van Deventer, S. J. H. (2001). Distribution and kinetics of lipoprotein-bound endotoxin. Infect. Immun. 69, 2821-2828. doi: 10.1128/iai.69.5.2821-2828.2001

Levine, D. M., Parker, T. S., Donnelly, T. M., Walsh, A., and Rubin, A. L. (1993). In vivo protection against endotoxin by plasma high density lipoprotein. Proc. Natl. Acad. Sci. U.S.A. 90, 12040-12044. doi: 10.1073/pnas.90.24.12040

Lewis, G. F., and Rader, D. J. (2005). New insights into the regulation of HDL metabolism and reverse cholesterol transport. Circ. Res. 96, 1221-1232. doi: 10.1161/01.RES.0000170946.56981.5c

Li, X. A., Titlow, W. B., Jackson, B. A., Giltiay, N., Nikolova-Karakashian, M., Uittenbogaard, A., et al. (2002). High density lipoprotein binding to scavenger receptor, Class B, type I activates endothelial nitric-oxide synthase in a ceramide-dependent manner. J. Biol. Chem. 277, 11058-11063. doi: 10.1074/jbc.M110985200

Li, Y., Dong, J.-B., and Wu, M.-P. (2008). Human ApoA-I overexpression diminishes LPS-induced systemic inflammation and multiple organ damage in mice. Eur. J. Pharmacol. 590, 417-422. doi: 10.1016/j.ejphar.2008.06.047

Lüscher, T. F., Landmesser, U., von Eckardstein, A., and Fogelman, A. M. (2014). High-density lipoprotein: vascular protective effects, dysfunction, and potential as therapeutic target. Circ. Res. 114, 171-182. doi: 10.1161/circresaha.114.300935

Martin, G. S., Mannino, D. M., Eaton, S., and Moss, M. (2003). The epidemiology of sepsis in the United States from 1979 through 2000. N. Engl. J. Med. 348, 1546-1554. doi: 10.1056/NEJMoa022139

Mendez, A. J., Lin, G., Wade, D. P., Lawn, R. M., and Oram, J. F. (2001). Membrane lipid domains distinct from cholesterol/sphingomyelin-rich rafts are involved in the ABCA1-mediated lipid secretory pathway. J. Biol. Chem. 276, 3158-3166. doi: 10.1074/jbc.M007717200

Mineo, C., Deguchi, H., Griffin, J. H., and Shaul, P. W. (2006). Endothelial and antithrombotic actions of HDL. Circ. Res. 98, 1352-1364. doi: 10.1161/01.res.0000225982.01988.93

Mineo, C., and Shaul, P. W. (2012). Novel biological functions of high-density lipoprotein cholesterol. Circ. Res. 111, 1079-1090. doi: 10.1161/circresaha.111.258673

Mineo, C., Yuhanna, I. S., Quon, M. J., and Shaul, P. W. (2003). High density lipoprotein-induced endothelial nitric-oxide synthase activation is mediated by Akt and MAP kinases. J. Biol. Chem. 278, 9142-9149. doi: 10.1074/jbc.M211394200

Ming, X. F., Barandier, C., Viswambharan, H., Kwak, B. R., Mach, F., Mazzolai, L., et al. (2004). Thrombin stimulates human endothelial arginase enzymatic activity via RhoA/ROCK pathway: implications for atherosclerotic endothelial dysfunction. Circulation 110, 3708-3714. doi: 10.1161/01.CIR.0000142867.26182.32

Moreira, R. S., Irigoyen, M., Sanches, T. R., Volpini, R. A., Camara, N. O. S., Malheiros, D. M., et al. (2014). Apolipoprotein A-I mimetic peptide 4F attenuates kidney injury, heart injury, and endothelial dysfunction in sepsis. Am. J. Physiol. Regul. Integr. Comp. Physiol. 307, R514-R524. doi: 10.1152/ajpregu.00445.2013

Munford, R. S. (2005). Detoxifying endotoxin: time, place and person. J. Endotoxin. Res. 11, 69-84. doi: 10.1179/096805105X35161

Munford, R. S., and Dietschy, J. M. (1985). Effects of specific antibodies, hormones, and lipoproteins on bacterial lipopolysaccharides injected into the rat. J. Infect. Dis. 152, 177-184. doi: 10.1093/infdis/152.1.177 
Murch, O., Collin, M., Hinds, C. J., and Thiemermann, C. (2007). Lipoproteins in inflammation and sepsis. I. Basic science. Intensive Care Med. 33, 13-24. doi: 10.1007/s00134-006-0432-y

Navab, M., Anantharamaiah, G. M., Reddy, S. T., Hama, S., Hough, G., Grijalva, V. R., et al. (2005). Apolipoprotein A-I mimetic peptides. Arterioscler. Thromb. Vasc. Biol. 25, 1325-1331. doi: 10.1161/01.atv.0000165694.39518.95

Navab, M., Reddy, S. T., Van Lenten, B. J., and Fogelman, A. M. (2011). HDL and cardiovascular disease: atherogenic and atheroprotective mechanisms. Nat. Rev. Cardiol. 8, 222-232. doi: 10.1038/nrcardio.2010.222

Nicholls, S. J., Uno, K., Kataoka, Y., and Nissen, S. E. (2011). ETC-216 for coronary artery disease. Expert Opin. Biol. Ther. 11, 387-394. doi: 10.1517/14712598.2011.557061

Nissen, S. E., Tsunoda, T., Tuzcu, E. M., Schoenhagen, P., Cooper, C. J., Yasin, M., et al. (2003). Effect of recombinant ApoA-I Milano on coronary atherosclerosis in patients with acute coronary syndromes: a randomized controlled trial. JAMA 290, 2292-2300. doi: 10.1001/jama.290.17.2292

Nofer, J.-R., Kehrel, B., Fobker, M., Levkau, B., Assmann, G., and Eckardstein, A. V. (2002). HDL and arteriosclerosis: beyond reverse cholesterol transport. Atherosclerosis 161, 1-16. doi: 10.1016/S0021-9150(01)00651-7

Ohashi, R., Mu, H., Wang, X., Yao, Q., and Chen, C. (2005). Reverse cholesterol transport and cholesterol efflux in atherosclerosis. QJM 98, 845-856. doi: 10.1093/qjmed/hci136

Pajkrt, D., Doran, J. E., Koster, F., Lerch, P. G., Arnet, B., van der Poll, T., et al. (1996). Antiinflammatory effects of reconstituted high-density lipoprotein during human endotoxemia. J. Exp. Med. 184, 1601-1608. doi: 10.1084/jem.184.5.1601

Patel, S., Drew, B. G., Nakhla, S., Duffy, S. J., Murphy, A. J., Barter, P. J., et al. (2009). Reconstituted high-density lipoprotein increases plasma highdensity lipoprotein anti-inflammatory properties and cholesterol efflux capacity in patients with type 2 diabetes. J. Am. Coll. Cardiol. 53, 962-971. doi: 10.1016/j.jacc.2008.12.008

Puff, N., Lamaziere, A., Seigneuret, M., Trugnan, G., and Angelova, M. I. (2005). HDLs induce raft domain vanishing in heterogeneous giant vesicles. Chem. Phys. Lipids 133, 195-202. doi: 10.1016/j.chemphyslip.2004.10.003

Quezado, Z. M., Natanson, C., Banks, S. M., Alling, D. W., Koev, C. A., Danner, R. L., et al. (1995). Therapeutic trial of reconstituted human high-density lipoprotein in a canine model of gram-negative septic shock. J. Pharmacol. Exp. Ther. 272, 604-611.

Raetz, C. R., and Whitfield, C. (2002). Lipopolysaccharide endotoxins. Annu. Rev. Biochem. 71, 635-700. doi: 10.1146/annurev.biochem.71.110601.135414

Read, T. E., Harris, H. W., Grunfeld, C., Feingold, K. R., Calhoun, M. C., Kane, J. P., et al. (1993). Chylomicrons enhance endotoxin excretion in bile. Infect. Immun. 61, 3496-3502.

Remaley, A. T., Amar, M., and Sviridov, D. (2008). HDL-replacement therapy: mechanism of action, types of agents and potential clinical indications. Expert Rev. Cardiovasc. Ther. 6, 1203-1215. doi: 10.1586/14779072.6.9.1203

Riedemann, N. C., Guo, R. F., and Ward, P. A. (2003). The enigma of sepsis. J. Clin. Invest. 112, 460-467. doi: 10.1172/JCI200319523

Riwanto, M., and Landmesser, U. (2013). High density lipoproteins and endothelial functions: mechanistic insights and alterations in cardiovascular disease. J. Lipid Res. 54, 3227-3243. doi: 10.1194/jlr.R037762

Sessler, C. N., Perry, J. C., and Varney, K. L. (2004). Management of severe sepsis and septic shock. Curr. Opin. Crit. Care 10, 354-363. doi: 10.1097/01.ccx.0000139363.76068.7b

Sethi, A. A., Stonik, J. A., Thomas, F., Demosky, S. J., Amar, M., Neufeld, E., et al. (2008). Asymmetry in the lipid affinity of bihelical amphipathic peptides: a structural determinant for the specificity of ABCA1-dependent cholesterol efflux by peptides. J. Biol. Chem. 283, 32273-32282. doi: 10.1074/jbc.M804461200

Shapiro, N. I., Schuetz, P., Yano, K., Sorasaki, M., Parikh, S. M., Jones, A. E., et al. (2010). The association of endothelial cell signaling, severity of illness, and organ dysfunction in sepsis. Crit. Care 14:R182. doi: 10.1186/cc9290

Singh, I. M., Shishehbor, M. H., and Ansell, B. J. (2007). High-density lipoprotein as a therapeutic target: a systematic review. JAMA 298, 786-798. doi: 10.1001/jama.298.7.786

Su, G. L. (2002). Lipopolysaccharides in liver injury: molecular mechanisms of Kupffer cell activation. Am. J. Physiol. Gastrointest. Liver Physiol. 283, G256G265. doi: 10.1152/ajpgi.00550.2001
Suzuki, M., Pritchard, D. K., Becker, L., Hoofnagle, A. N., Tanimura, N., Bammler, T. K., et al. (2010). High-density lipoprotein suppresses the type I interferon response, a family of potent antiviral immunoregulators, in macrophages challenged with lipopolysaccharide. Circulation 122, 1919-1927. doi: 10.1161/CIRCULATIONAHA.110.961193

Tardif, J. C., Grégoire, J., L’Allier, P. L., Ibrahim, R., Lespérance, J., Heinonen, T. M., et al. (2007). Effects of reconstituted high-density lipoprotein infusions on coronary atherosclerosis: a randomized controlled trial. JAMA 297, 1675-1682. doi: 10.1001/jama.297.15.jpc70004

Tsai, M. H., Peng, Y. S., Chen, Y. C., Lien, J. M., Tian, Y. C., Fang, J. T., et al. (2009). Low serum concentration of apolipoprotein A-I is an indicator of poor prognosis in cirrhotic patients with severe sepsis. J. Hepatol. 50, 906-915. doi: 10.1016/j.jhep.2008.12.024

Ulevitch, R. J., Johnston, A. R., and Weinstein, D. B. (1979). New function for high density lipoproteins. Their participation in intravascular reactions of bacterial lipopolysaccharides. J. Clin. Invest. 64, 1516-1524. doi: 10.1172/ JCI109610

Ulevitch, R. J., Johnston, A. R., and Weinstein, D. B. (1981). New function for high density lipoproteins. Isolation and characterization of a bacterial lipopolysaccharide-high density lipoprotein complex formed in rabbit plasma. J. Clin. Invest. 67, 827-837. doi: 10.1172/JCI1 10100

Van Amersfoort, E. S., Van Berkel, T. J., and Kuiper, J. (2003). Receptors, mediators, and mechanisms involved in bacterial sepsis and septic shock. Clin. Microbiol. Rev. 16, 379-414. doi: 10.1128/CMR.16.3.379-414.2003

van Leeuwen, H. J., Heezius, E. C., Dallinga, G. M., van Strijp, J. A., Verhoef, J., and van Kessel, K. P. (2003). Lipoprotein metabolism in patients with severe sepsis. Crit. Care Med. 31, 1359-1366. doi: 10.1097/01.CCM.0000059724. 08290.51

Van Lenten, B. J., Fogelman, A. M., Haberland, M. E., and Edwards, P. A. (1986) The role of lipoproteins and receptor-mediated endocytosis in the transport of bacterial lipopolysaccharide. Proc. Natl. Acad. Sci. U.S.A. 83, 2704-2708. doi: 10.1073/pnas.83.8.2704

Van Lenten, B. J., Wagner, A. C., Anantharamaiah, G. M., Garber, D. W., Fishbein, M. C., Adhikary, L., et al. (2002). Influenza infection promotes macrophage traffic into arteries of mice that is prevented by $D-4 F$, an apolipoprotein A-I mimetic peptide. Circulation 106, 1127-1132. doi: 10.1161/01.cir.0000030182.35880.3e

Vickers, K. C., and Remaley, A. T. (2014). HDL and cholesterol: life after the divorce? J. Lipid Res. 55, 4-12. doi: 10.1194/jlr.R035964

Vincent, J. L., Rello, J., Marshall, J., Silva, E., Anzueto, A., Martin, C. D., et al. (2009). INternational study of the prevalence and outcomes of infection in intensive care units. JAMA 302, 2323-2329. doi: 10.1001/jama.2009.1754

Vishnyakova, T. G., Bocharov, A. V., Baranova, I. N., Chen, Z., Remaley, A. T., Csako, G., et al. (2003). Binding and internalization of lipopolysaccharide by Cla-1, a human orthologue of rodent scavenger receptor B1. J. Biol. Chem. 278, 22771-22780. doi: 10.1074/jbc.M211032200

Viswambharan, H., Ming, X. F., Zhu, S., Hubsch, A., Lerch, P., Vergeres, G., et al. (2004). Reconstituted high-density lipoprotein inhibits thrombininduced endothelial tissue factor expression through inhibition of RhoA and stimulation of phosphatidylinositol 3-kinase but not Akt/endothelial nitric oxide synthase. Circ. Res. 94, 918-925. doi: 10.1161/01.RES.0000124302. 20396.B7

von Eckardstein, A., Nofer, J.-R., and Assmann, G. (2001). High density lipoproteins and arteriosclerosis: role of cholesterol efflux and reverse cholesterol transport. Arterioscler. Thromb. Vasc. Biol. 21, 13-27. doi: 10.1161/01.atv.21.1.13

Warren, H. S., Amato, S. F., Fitting, C., Black, K. M., Loiselle, P. M., Pasternack, M. S., et al. (1993). Assessment of ability of murine and human anti-lipid A monoclonal antibodies to bind and neutralize lipopolysaccharide. J. Exp. Med. 177, 89-97. doi: 10.1084/jem.177.1.89

Yan, Y.-J., Li, Y., Lou, B., and Wu, M.-P. (2006). Beneficial effects of ApoA-I on LPS-induced acute lung injury and endotoxemia in mice. Life Sci. 79, 210-215. doi: 10.1016/j.lfs.2006.02.011

Yuhanna, I. S., Zhu, Y., Cox, B. E., Hahner, L. D., Osborne-Lawrence, S., Lu, P., et al. (2001). High-density lipoprotein binding to scavenger receptor-BI activates endothelial nitric oxide synthase. Nat. Med. 7, 853-857. doi: 10.1038/ 89986 
Yvan-Charvet, L., Welch, C., Pagler, T. A., Ranalletta, M., Lamkanfi, M., Han, S., et al. (2008). Increased inflammatory gene expression in ABC transporter-deficient macrophages: free cholesterol accumulation, increased signaling via toll-like receptors, and neutrophil infiltration of atherosclerotic lesions. Circulation 118, 1837-1847. doi: 10.1161/CIRCULATIONAHA.108. 793869

Zhang, X., Wang, L., and Chen, B. (2015). Recombinant HDL (Milano) protects endotoxin-challenged rats from multiple organ injury and dysfunction. Biol. Chem. 396, 53-60. doi: 10.1515/hsz-2014-0188

Zhang, Z., Datta, G., Zhang, Y., Miller, A. P., Mochon, P., Chen, Y.-F., et al. (2009). Apolipoprotein A-I mimetic peptide treatment inhibits inflammatory responses and improves survival in septic rats. Am. J. Physiol. Heart Circ. Physiol. 297, H866-H873.

Zhu, X., Lee, J. Y., Timmins, J. M., Brown, J. M., Boudyguina, E., Mulya, A., et al. (2008). Increased cellular free cholesterol in macrophagespecific Abcal knock-out mice enhances pro-inflammatory response of macrophages. J. Biol. Chem. 283, 22930-22941. doi: 10.1074/jbc.M801 408200

Zhu, X., and Parks, J. S. (2012). New roles of HDL in inflammation and hematopoiesis. Annu. Rev. Nutr. 32, 161-182. doi: 10.1146/annurev-nutr071811-150709

Conflict of Interest Statement: The authors declare that the research was conducted in the absence of any commercial or financial relationships that could be construed as a potential conflict of interest.

Copyright (c) 2015 Morin, Guo, Schwendeman and Li. This is an open-access article distributed under the terms of the Creative Commons Attribution License (CC BY). The use, distribution or reproduction in other forums is permitted, provided the original author(s) or licensor are credited and that the original publication in this journal is cited, in accordance with accepted academic practice. No use, distribution or reproduction is permitted which does not comply with these terms. 